\title{
A Case Study of Factors Affecting the Performance of the Hotel Industry of Chiang Mai in Thailand and the Impact of Covid-19: Taking De Chai Hotel Group as an Example
}

\author{
Jui-Lung Chen ${ }^{1}$ and Kusumalee Kitingern ${ }^{2}$
}

\begin{abstract}
Tourism has made a significant contribution to Thailand's economy, bringing considerable tourism revenue to Thailand every year, and driving the sustained growth of related industries. This study focused on the factors that affect the performance of the hotel industry of Chiang Mai in Thailand, taking De Chai Hotel Group, a local large-scale hotel group, as a case study, and discussed the impact of COVID-19 on it and its countermeasures. This study also put forward relevant suggestions as a reference for the hotel industry to formulate management strategies and future development.
\end{abstract}

JEL classification numbers: L25, L83.

Keywords: Tourism, Hotel industry, Performance, COVID-19.

\footnotetext{
${ }^{1}$ Department of Business Administration, National Chin-Yi University of Technology, Taiwan, R.O.C

${ }^{2}$ Department of Business Administration, National Chin-Yi University of Technology, Taiwan, R.O.C
} 


\section{Introduction}

Tourism plays a crucial role in Thailand's economy and brings considerable benefits to the country every year. Tourism is also Thailand's largest source of foreign exchange income and an important pillar of Thailand's economy. In recent years, the number of foreign tourists visiting Thailand every year has also grown steadily, which has also driven the vigorous development of tourism and related service industries, especially the hotel industry. Driven by the Thai government's policies, the hotel industry has gained steady growth throughout the country, which is mainly driven by foreign tourists visiting tourist attractions in various provinces. In particular, the popularity of provinces with airports offering international flights and a steady increase in the number of foreign tourists have boosted Thailand's economy. Thailand's diversified tourism demand is one of the reasons why tourism attracts special attention from international tourists. However, travel demands are complex. These complexities are caused by major changes, such as changes in population, structure and tourist background, but there are more and more new tourists (Suwannaphong, 2020).

Among the 10 ASEAN countries, Thailand is the second-largest economy, with the gross domestic product (GDP) second only to Indonesia. According to a report by Thailand's Ministry of Commerce, the service industry accounted for the largest proportion of Thailand's GDP in 2018, up 9.2\% from 2017. Other major industries include electronic motors, automobile manufacturing, food processing, aquatic products processing, etc. (Taiwan External Trade Development Council, 2020). Dato Seri Setia Haji Ali, Chairman of the ASEAN Tourism Ministers' Meeting, stated at the 2020 ASEAN Tourism Forum that ASEAN's tourism industry has maintained growth in the past decade and will continue to contribute to the socioeconomic development of the region. ASEAN received about 133 million tourists in 2019, an increase of about $7 \%$ over 2018,37\% of whom were tourists from within ASEAN. Tourism revenue directly affected the regional economy, investment and labor force. ASEAN is aware of the need to keep pace with the times for a new generation of young tourists. With the development of innovative technologies and the changing preferences and needs of tourists, these destinations need a new tourism development strategy and should strengthen regional cooperation with ASEAN partners, including sustainable and inclusive development (TTG China, 2020). According to Thai government data, the number of tourists arriving in Thailand reached a record of 41.1 million in 2019, an increase of about $8 \%$ from 38.3 million in 2018, while the total tourism revenue exceeded THB3000 billion, ranking fourth in the world (Bloomberg Businessweek, 2019). However, the COVID-19 has caused a great impact on the global tourism industry hard. According to the data of Thailand's National Economic and Social Development Council, Thailand's economy shrank for the first time in six years in the first quarter of 2020, and GDP in the first quarter also shrank by $1.8 \%$ compared with the same period last year, the first shrinkage since 2014. Among them, the number of inbound tourists dropped by nearly $40 \%$ compared with the same period last year. Thailand 
has beautiful beaches, colorful nightlife and street snack culture. It was originally estimated that the number of inbound tourists would reach about 40 million in 2020. However, the outbreak has seriously affected Thailand's tourism industry. Thailand's National Economic and Social Development Council estimated that Thailand's economy will shrink by $5 \%$ to $6 \%$ in 2020 . This will be the largest contraction in Thailand's economy since the Asian financial crisis from 1997 to 1998. The International Monetary Fund (IMF) further estimated that Thailand's economy will shrink by $6.7 \%$ in 2020 , and Thailand may become the worstperforming country in Southeast Asia (UDN, 2020).

Bangkok is the capital of Thailand and the first largest city. It is also located at the hub of the country and is an administrative, financial, economic, industrial and commercial center. Chiang Mai is the industrial and commercial center in northern Thailand, the second-largest city and an important agricultural and sightseeing town. However, its industrial and commercial development lags slightly behind Bangkok and (Taiwan External Trade Development Council, 2020). Thailand's hotel industry is quite developed. The rapid growth of tourism has led to a growing number and scale of hotels. In 2016, nearly 10 million Thai and foreign tourists visited Chiang Mai, according to Thailand's National Statistical Office. Chiang Mai's hotel industry began to develop rapidly in 2013, with the number of hotels jumping from 1,698 to 6,908 in 2016 (National Statistical Office of Thailand, 2020). With the development of the social economy and the improvement of civilization, tourism products have become necessities of life from luxury goods, and the tourism market has evolved from a niche market to a mass market. Tourism is the leading industry in the third industry. Damage to the leading industry will reduce the overall consumption demand. Considering the multiplier effect of tourism, the blocking effect of the epidemic on tourism consumption will affect the upstream and downstream industries of the tourism industry chain, especially the hotel industry (Yan and Yan, 2020). Due to the sudden outbreak of the epidemic and its strong and wide spread, tourism factor enterprises are affected by it one after another. Tourism is a kind of leisure and entertainment activity for people and a way of life that brings spiritual and cultural enjoyment. As safety is the first factor to be considered in tourism, people may cancel their travel plans due to any safety factor. As a result of the epidemic, people lost their interest in traveling and their demand for tourism was suppressed. As the COVID-19 may spread due to traveling, the travel demands are rapidly weakened and travel agencies, hotels and even scenic spots see a large number of tour group cancellations and refunds (Ming and Zhong, 2020). Therefore, this study discussed the factors that affect the performance of Thailand's Chiang Mai hotel industry, taking the local large-scale De Chai Hotel Group as the case study, and explored the impact of COVID-19 on it and its countermeasures. This study also put forward some strategic suggestions for the hotel industry in the region, which will serve as a reference for future improvement direction and development. 


\section{Literature Review}

Thailand is located in the tropics, with a small temperature difference throughout the year and a warm climate conducive to health. Its consumption level is not high and prices are relatively low. Besides, Thailand has 11 traditional festivals featuring profound cultural traditions and historical details. At the same time, most citizens believe in Mahayana Buddhism, which greatly increases people's interest in Thai cultural tourism. Even some tourists go to experience Thai festivals and Buddhist atmosphere, which has promoted the development of cultural tourism and religious tourism in Thailand. By virtue of the strength of culture, the hotel industry develops its own characteristic business in terms of hotel site selection, architectural style and religious services (Chen, Geng and $\mathrm{Wu}, 2016$ ). The Thai government also attaches great importance to and strengthens tourism research and tourism planning. Tourism management departments at all levels have set up special research institutions, equipped with advanced data analysis and processing equipment and high-level researchers. Thailand's tourism research departments have formulated a thorough and detailed research plan and specific research topics every year (Wang et al., 2009). The history of Thailand's tourism industry can be traced back to 1924 . Siam's Royal State Railways Department set up a Ministry of Public Relations to promote Thailand's tourism and provide necessary assistance to foreign tourists. In 1959, Thailand established the Tourist Organization of Thailand and Thai Airways through a joint venture. In the late 1970s, Thailand's economy slowed down, so tourism became the main source of foreign exchange earnings (Yang, 2017). Thailand is an open tourism country, and the development of the tourism economy and the prosperity of the tourism market have received great attention in the world. More and more tourists from all over the world, especially Europe, North America, Japan, and Asia, visit Thailand year by year, and the average number of days of stay has also increased significantly (Wang et al., 2009). The major significance of the rise of Thailand's tourism economy is that the whole society has nurtured the environment of modernization and transformation. It can be said that the overall social change has boosted Thailand's tourism economic development. This is probably due to the basic contents and characteristics that constitute Thailand's development model, which meet the requirements of the modern market economy, the requirements of the integration of the contemporary world economy, and the specific national conditions of Thailand (Wu, 2014).

In addition to handicrafts and textiles, Thai also offers characteristic tourism services for tourists, such as Thai massage, hot springs, Thai boxing art performances, beauty care, etc. Besides, some original ecological resources can also be developed into tourism resources with special features. Also, Thailand boasts diversified tourism resources, beautiful natural scenery, a favorable geographical location and a warm climate suitable for year-round tourism. The Thai people are hospitable and welcome foreign tourists with an open mind (Ai, 2014). Thailand is rich in tourism resources, and Thailand ranks first in many tourism magazines or websites. High-quality tourism resources can naturally attract many tourists to 
Thailand, thus driving the development of the hotel industry (Chen et al., 2016). Thailand's tourism revenue is increasing year by year. The Thai government also fully supports the development of Thailand's tourism market, including support for foreign tourists to visit Thailand and for domestic tourists to travel to China. The government actively promotes the market at home and abroad, hoping Thailand can become a world-class tourism center (Ai, 2014). Tourism is one of the largest industries in the world. Due to its rapid development and great success, tourism is mostly cultivated as the leading industry or pillar industry of the local economy. Thailand's tourism industry is booming. Foreign exchange income from tourism occupies the first place in the country's foreign exchange income. Tourism has become the most important pillar industry in Thailand. The country regards the development of tourism as a means to stimulate domestic economic growth. Moreover, the development of Thailand's hotel industry has maintained a strong growth trend in the past 20 years (Miao, 2020).

In regions and countries where tourism is highly developed, they should make good use of their unique environmental resources, invest in infrastructure, and create a sound environment, such as perfect market rules, convenient commerce and trade, prosperous regional processing industry, international trade, high-quality employees, open market, etc. These conditions serve as the premise for achieving long-term prosperity. Therefore, Thailand's thriving tourism industry is inseparable from its relatively perfect and developed market economy environment ( $\mathrm{Wu}, 2014)$. COVID-19, which broke out around January 2020, spread rapidly around the world, causing a serious impact on global economic and social development and people's lives. Traditional tourism refers to the tourism industry composed of travel agencies, scenic spots, hotels and other industries that provide services for tourists for sightseeing purposes. COVID-19 has caused a severe impact on traditional tourism (Miao, 2020). It is a sudden public health event. How to understand its impact on tourism and adopt coping strategies in advance to minimize the negative impact is a major issue currently facing us. Tourism is the most responsive and sensitive to changes in the external environment and is the most vulnerable to public events, especially public emergencies that have the most profound impact on the sustainable development of tourism. COVID-19 has an overall impact on the development of tourism in three aspects: Wide, severe and far-reaching impact (Ming and Zhong, 2020). Tourism is one of the industries most affected by COVID-19. The losses suffered by tourism are not only reflected in the decrease of industry income, but also in the macro-economic and social level through industrial and social connections (Yan and Yan, 2020). Tourism is a unique industry, covering the primary industry, the secondary industry and the tertiary industry. It is a comprehensive industry of the national economy, overlaps with part of commerce, industry and agriculture, and is closely related to the catering industry and accommodation industry in the service industry. The restoration of tourism is crucial to the promotion of the national economic complex (Miao, 2020). Tourism activities are characterized by high intensity, direct contact and extensive flow, which easily lead to the rapid spread of epidemic space and even incalculable 
consequences. In light of the high coupling between the mobility of tourism space and the spread of the epidemic, strict measures are taken to block the flow of people due to the epidemic. Most places are "shut down" and the flow of tourism comes to an abrupt end, approaching zero flow. Due to the need for epidemic prevention and control, the development of tourism will undoubtedly be greatly affected before the epidemic crisis is relieved (Ming and Zhong, 2020).

\section{Methodology}

Thailand's tourism industry is growing rapidly. In this regard, Thailand is constantly adjusting its basic plan. It built a modern Suvarnabhumi Airport to accommodate more passenger flow. To reduce the passenger flow pressure of Suvarnabhumi Airport, Don Mueang Airport is also put into use. In terms of land transportation, vehicles and trains are available around the country, and tourists can go anywhere in Thailand (Ai, 2014). Chiang Mai is Thailand's 5th largest city and Thailand's 3rd largest tourist resort. This study took De Chai Hotel Group, a local large-scale hotel group, as a case study to explore the factors that affect the performance of Thailand's Chiang Mai hotel industry, and to probe into the impact of COVID-19 on it and its countermeasures. Yin (1994) defined a case study as one of the types of social science research and developed the topology of case study design. Case studies often establish theoretical constructs and propositions through single or multiple cases or establish medium-range theories through case-based empirical evidence (Eisenhardt, 1989). De Chai Hotel Group is successful in the hotel business in Chiang Mai. It has three hotels with room prices between THB 2,800 and THB 6,000 . It outperforms its peers in terms of convenient accommodation facilities, innovative design and decoration, which are the attraction of the hotel. Moreover, the Group plans to build another hotel by 2022. This study intended to understand the factors that affect the performance of the De Chai Hotel Group and the reasons for its success. In this study, qualitative research was used to interview seven personnel of De Chai Hotel Group, including business owners, managers, receptionists and housekeepers in an in-depth manner. The interview was carried out in a semi-structured fashion and was divided into five main topics so as to discuss from different angles. Interviewees gained a better understanding of the research topic through previous relevant literature discussions. In this aspect, the semi-structured interview allowed interviewers and interviewees to engage in more in-depth dialogues and discussions. The first topic is personal information about the interviewees, which may help to find out whether the interviewees meet the criteria expected in this study. Background information is a measure of information about basic knowledge and information about the hotel business. This part can also make the interviewees more familiar with the research topic so that they can prepare for further questions. The second topic is about personal performance and how to address problems encountered at work. The purpose of the interviewers was to better understand how the interviewees were willing to provide services for the hotel. The third part is to understand how to improve the service quality of employees in 
reception departments and other departments. To obtain more professional information, researchers conducted formal and informal interviews respectively to have a deeper understanding of the hotel business. The fourth part focuses on the factors of how to successfully carry out the business and the hotel's marketing plan. It is hoped that this part can provide a theoretical basis for customer service needs. The last part focuses on the external factors that affect the customers who use hotel services and the influence of COVID-19 and the response of the hotel. The interview for this study was conducted in Chiang Mai, Thailand from October 2019 to April 2020. Due to the consideration of epidemic factors and time constraints, this study adopted social media tools for video interviews.

\section{Interview Results}

\subsection{Interviews with Business Owners}

Owners of large hotels usually consider the income and value of the hotel business. Mr. Suthep Chawla, the owner of the Chiang Mai DE CHAI HOTEL GROUP in Thailand, commented on the operation of the hotel business in Chiang Mai, Thailand, one of the provinces with the highest tourism revenue. Business risks must be taken into account. Mr. Suthep Chawla said in the interview, "Chiang Mai is a large tourist destination and has had a positive impact on the hotel business. It is possible to run the hotel business on a par with their previous business. With an increasing income, available land, and an advantageous geographical location covering many areas of Chiang Mai, I tried to start a hotel business and I wanted to try my best." The hotel business is a 4-star hotel in Chiang Mai. Its decoration is beautiful. And each branch of the hotel was decorated differently according to the area. It was not hard to make such an investment. In the future, it is planned to continuously expand branches. The latest plan is to build another hotel branch in the next two years. Mr. Suthep Chawla was convinced that the hotel business will develop smoothly. They would provide high-quality services. For example, they would pay attention to whether the reservation date is a special day, promotion activities during peak season, customers' birthdays, whether to accept travel plan reservations, airport shuttle service for booking cars, etc. All these have affected the hotel business he founded. All these may improve customer loyalty, arouse customer attention and attract them to visit again. Mr. Suthep Chawla added that trivial matters such as regular hotel maintenance cannot be ignored. Also, updated payment systems and various channels of convenient and fast access to hotels are other factors that make the hotel business successful. The labor cost is an important expense in the hotel industry during the epidemic shutdown. During the epidemic featuring no cash flow, it is an important channel for enterprises to cut expenditures (Yan and Yan, 2020). COVID-19 had a wide range of influence, thereby affecting the performance of many travel-related enterprises and the related industries, leading to capital chain crack and making tourism personnel "lose their jobs". Besides, these enterprises and industries faced huge financial pressure when they were out of business. Labor costs, early operation and marketing costs and other 
operation and maintenance costs cannot be recovered. Moreover, they had to pay for employee wages and loans, make early payment and refunds. In the short term, tourism enterprises and tourism personnel were plagued by increasing pressure (Ming and Zhong, 2020).

\subsection{Interviews with Managers}

Mr. Wallop Manoonthe, manager of DE CHAI HOTEL GROUP, said that the hotel has three golden locations, each of which had a different background from those who had previously lived there. Whether it is a shopping area or a place home to many temples, tourists can also stroll, ride bicycles and take photos in the city. Though Chiang Mai is a multi-cultural center, it has not hindered the growth of tourism. Profits can be made in many places in Chiang Mai. The hotel business of DE CHAI HOTEL GROUP is different from that of other hotels, with the latter intending to keep each branch in a consistent style. No one stands out like DE CHAI HOTEL GROUP. All three branches have their unique styles. It can help customers choose the area they want to travel to. Thus, DE CHAI HOTEL GROUP can continue to develop although it has many competitors in the city of Chiang Mai. As for marketing plans, he said: In an era when everyone can access the Internet without having to go out and distribute leaflets on their own, it is convenient to book rooms at discounted prices. Also, hotels will arrange birthday parties and free airport transportation to make customers feel that staying in hotels is worthwhile. Customers can obtain the services they pay for, and hotels may maintain highquality services. Employees in different positions are an important aspect of hotel services. Most employees are considering service attitude. The language they used every day is decided by over $80 \%$ of foreigners living in Thailand, and the hotel also provides job opportunities for new graduates. Graduates with little or no experience, like experienced personnel, can learn to work fast. In light of problems caused by high payment or slow-learners, the manager described in detail the marketing plan of hotel researchers to absorb knowledge. Because he is a manager, he must supervise all three branches of Chiang Mai, and pay special attention to marketing and employee services.

As the target group of the hotel is often foreigners, the hotel is located close to the main tourist attraction in Chiang Mai, Thailand, but it still cannot attract the attention of foreigners. Thus, the hotel used some famous mobile applications such as Booking.com, Agoda, Trip Advisor, Airbnb and Trivago, which can be accessed in many areas, to provide accommodation reservation service. The manager said that comfortable accommodation can be found in America, Europe and Asia. It is not easy to attract customers in business. Since many competitors perform well, heartfelt service is a top priority for hotel staff. Is it to greet with a smile after customers enter the hotel gate or to seek convenience during the stay? It is also important to help identify important tourist destinations in Chiang Mai and allocate local taxis or vans for customers, all of which are aimed at maximizing customer satisfaction and choosing the hotel in the future. 


\subsection{Interviews with Receptionists and Housekeepers}

There were five interviewees, with A-E as the code. During the interview, the Covid-19 virus has spread rapidly in Thailand. As a result, Chiang Mai had almost no tourists, and become a quiet city that researchers had never seen in their lives. Thailand's airspace has also been completely closed by the government.

\subsubsection{Interviewee A, 26-year-old Full-time Receptionist}

Her services have left a deep impression on customers. She said that it is necessary to pay attention to the needs of customers to make them feel that the hotel is like another house more comfortable than ordinary houses. She also said that the hotel, different from those of other hotels makes customers feel at home. Customers would not feel uncomfortable when asking questions or seeking her help. They can book buses to various tourist attractions when booking travel plans. Teamwork will be carried out based on customer satisfaction, which will have a great impact on her work efficiency, such as making her feel comfortable at work. She can always ask for help to make work go smoothly.

\subsubsection{Interviewee B, 31-year-old Full-time Receptionist}

She has worked in the hotel for more than a year. She shared the reason for the success of the hotel: The hotel has three branches in all tourist locations, allowing customers to choose accommodation according to their needs. Waiting and asking customers will make customers feel that the hotel takes care of them very much. She also mentioned that working with colleagues is an important factor in the work process, which makes her more productive. Customers can talk with her freely and she may understand the ideas of customers. They can talk about problems at any time like family members. Thus, she enjoys the job and likes to provide better services.

\subsubsection{Interviewee C, 24-year-old Full-time Receptionist}

He was a man working from 11 o'clock late at night to the night of the following day. He has less than one year's work experience. He did not think staying out late is a problem. Instead, he thought that such working time is comfortable because it was time for customers to rest and sleep. His job was to manage hotel reservation documents through the following methods: Hotel system. Waiting to help customers who travel only at night is an easy task for him. He may have straight days off every month, "The reception department assists customers 24 hours a day to handle emergencies. Night watch is comfortable. But even so, he should be prepared to address all kinds of situations that may happen at any time. Though there are few employees at night, he thought that his work is very important. For example, a quarterback is important and he is the quarterback of DE CHAI. Although he has less work experience, he is satisfied with his work every day because Thailand closes tourist attractions and entertainment venues at midnight and everyone returns to the hotel at 11 p.m. He was not very busy until 1 a.m. Mr. C said that customers 
are not the enemies in his work. He sometimes will get tired because of the too many demands of customers. He had to drink coffee every night to finish his working hours.

\subsubsection{Interviewee D, 28-year-old Full-time Receptionist}

The third branch is new. At that time, the hotel was busy. We need to help customers when they have questions or need travel information. In addition to providing services in a friendly way, we need to update information about tourist attractions and other aspects. There is also the responsibility of employees like me, because new places in Chiang Mai appear at any time, such as coffee shops in the forest, folk restaurants, new elephant performances and entertainment venues or thrilling activities. I must know the locations of these interesting places. Since each customer has different travel needs, we need to correctly and accurately answer questions of customers and learn new information. Therefore, this is another important job, which will make customers make easier decisions when choosing each trip. I want to try to find the best travel choice for them. Hotels that sign contracts with airlines are time-saving and comfortable because the space shuttle will pick up customers quickly within a few minutes of dialing. Customers do 'not have to wait for a long time or waste time ordering cold drinks when there is a restaurant, which may be the reason why the hotel is successful. She said she was proud of her work in the hotel.

\subsubsection{Interviewee E, 35-year-old Full-time Housekeeper}

She is an experienced housewife. She was transferred from another branch to work in the branch nearest to her home. She pays special attention to cleaning. The layout of a comfortable living space is considered to be the priority of the hotel. Whether it's making the bed, changing pillowcases, covering blankets and preparing bathroom accessories, you need to make customers feel at home. It is very important to keep clean to meet the standards, satisfy customers and leave a good impression. No one wants to stay in a dirty hotel or a hotel with insects. Thus, I attach great importance to cleanliness. I need to make customers feel convenient. After a customer left, I had to make sure that everything in the room was in good condition. It may meet the standard for a new customer to stay in the next hour. No one is willing to pay you if you behave improperly. Smelly room, dirty bathroom, or empty shampoo will not be tolerated. However, something that you do not want to happen always happens, such as the stinking pipes in the bathroom, which has always been a problem. As a result, she had to call hotel maintenance technicians frequently, but this situation continued to happen because there had been problems with the water pipes since the hotel layout had gone wrong. She said that compared with other branches, her branch spends more on deodorant products. Even the branch has the least number of rooms.

Through interviews with hotel owners, managers and employees working in the hotel, it can be seen that everyone pays great attention to service and strives to make 
the hotel a high-standard one. They provide friendly service, teamwork and sincere attention to customers to make the hotel function smoothly even if a serious Covid19 virus outbreak occurs in Thailand. Although Covid-19 led to a sharp drop in the number of tourists, the DE CHAI HOTEL GROUP still maintained the same high standard. Interviews show that sincere service is very important. Success depends on many factors.DE CHAI HOTEL GROUP plans to upgrade from an international company to a global company. Raise your hand to pay tribute in Thai style. You must start everything from the bottom of your heart. Raising your hand in honor of customer service is an important thing that must be observed or done from your heart.

Looking back on the success of the large hotel business in Chiang Mai, Thailand, the hotel has excellent management, especially the development and management of human resources. The hotel is aware of the importance of human resources development. It is necessary to build up morale in the work. Besides, it is necessary to maintain a relationship with the organization, such as organizing birthday parties for employees or exchanging gifts on important days or providing bonuses to outstanding employees. Training activities and off-site human resources development activities will also be carried out to enhance employees' behavior so that they feel loved like family members. This study interview highlights the importance of encouraging employees to recognize service-related changes, which is also important to motivate enterprises to achieve their goals. The study results are also consistent with performance research. Performance is the main multidimensional structure aimed at achieving results and is strongly linked to the strategic objectives of the organization. Employee performance is work-related activities and the extent to which employees perform these activities. In fact, not every employee's behavior is classified as the concept of poor performance. The behaviors of employee demand are related to the organization's goals, such as increasing the organization's sales and profits.

\section{Results and Discussion}

Thailand is a country rich in tourism resources. Its tourism revenue accounts for a considerable proportion of the country's total revenue and has become an important pillar of its national economy. Thailand's tourist hotel industry is prosperous, covering all tourist attractions and cities. If COVID-19 lasts for a long time and causes serve impact on the tourism industry, there will be a risk of industry-wide unemployment in the tourism industry, which is not conducive to the stability of the overall social situation. In the long run, the impact of the epidemic on tourism is temporary. Tourism merchants should predict the depression, growth and recovery of the tourism industry. Tourism will not recover as immediate as that of the manufacturing industry, and there will be a lag period (Yan and Yan, 2020). The impact of the epidemic on the tourism industry includes not only the real direct losses of many tourism enterprises and related employees, but also the indirect losses of various related industries. The severe COVID-19 has brought about great 
changes in macro-economy, tourism consumption structure and tourism industry structure. The specific impact time of COVID-19 on tourism depends on the duration of the epidemic and the intensity of policy hedging.COVID-19 is highly transmissible and is of a spread area. Correctly assessing its impact on tourism is of great importance to the recovery and revitalization of tourism after the epidemic. To promote the healthy development of tourism, efforts should be made to perfect the management mechanism of the tourism crisis, as well as enrich and expand the research content of the tourism crisis (Ming and Zhong, 2020). Currently, Thailand hotels are mostly tourism-oriented hotels, so how to enhance market expansion to form hotel characteristics, possess high-quality service, and outperform peers is the problem that should be solved by investors in the hotel industry in Thailand (Chen et al., 2016).

For small and medium-sized tourism enterprises, the depression period when offline tourism business is suspended does not mean that business is suspended. The depression period of offline tourism business is an extraordinary period when people are staying at home or when their normal life is affected. From the perspective of tourism psychology, it is a process of accumulating tourism demand. Therefore, it may be an effective means to maintain customer stickiness and retain tourists during the recession to push all kinds of tourism product information to potential tourists through the network means. Enterprises should make plans in advance based on the analysis of tourism demand after the epidemic, communicate with upstream and downstream enterprises in the industrial chain, integrate resources and innovate products (Yan and Yan, 2020). In response to COVID-19 and the limitation of tourism scope, many countries are actively discussing the feasibility of the travel bubble. As countries decide how to restart international tourism and business during the COVID-19, the idea of tourism bubbles (sometimes also called travel corridors) is gradually emerging. The concept of a travel bubble is simple: A bubble is formed between two or more countries that have successfully defeat COVID-19, and then people living in the bubble can travel freely without having to comply with mandatory self-quarantine requirements. Such a move will cut red tape and enable people to cross the border with minimal trouble to achieve the purpose of international sightseeing exchanges (Feng, 2020). Therefore, it is suggested that the Thai government should actively negotiate with other countries. Besides, supported by relevant policies and funding, the tourism industry can hold various activities such as large-scale festivals, conferences and exhibitions after the epidemic, and can also carry out various forms of marketing activities such as discount weeks, discount months, discount seasons, online promotions, etc. Tourism is entering the era of overall tourism. Facing the crisis, the tourism industry is embarking on the path of transformation and is in need of joint efforts of all parties. An objective and comprehensive analysis of the impact of the epidemic on the tourism industry allows the tourism industry to survive during the epidemic. In this regard, reducing losses is an urgent problem to be solved at present (Miao, 2020). Moreover, the government should pay close attention to the epidemic prevention and control, assess the situation, strengthen crisis management, and guide tourism 
enterprises to actively cope with the situation. Besides, efforts should be made to develop new formats, promote new and diversified businesses and innovate tourism projects; create personalized, characteristic and competitive products, strengthen online marketing efforts, do a good job of "open source", lay the foundation for the post-epidemic situation, and adapt to the new rebound retaliatory consumption growth after the epidemic (Ming and Zhong, 2020). As long as the epidemic is successfully prevented and controlled, the demand for tourism and leisure will be released quickly, and even explosive compensatory consumption as that in Taiwan's tourism market may occur.

\section{References}

[1] Ai, L. (2014). SWOT Analysis of Tourism Development in Thailand, Zhishi Jingji, 2014 (5), 98-103.

[2] Bloomberg Businessweek (2019). Tourism Minister Worries that the Number of Tourists in Thailand will Exceed 40 million in 2019. Available from: http://read.bbwc.cn/dl1kio.html.

[3] Chen, M., Geng, S. and Wu. L. (2016). Analysis on Investment Path of Hotel Industry in the Context of the Belt and Road Initiative-Taking Thailand and Russia as Examples, China Market Marketing, 50, 73-74.

[4] Eisenhardt, K. (1989). Building Theories from Case Study Research, Academy of Management Journal, 14(4), 532-550.

[5] Feng, H. (2020). Crisis is Turning Point: Comprehensive Tourism Development for Domestic Tourism after COVID-19, Journal of Tourism and Leisure Management, 8, 46-55.

[6] Miao, Q. (2020). Impact of COVID-19 on Tourism, Wen Yuan, 2020 (1), 248249.

[7] Ming, Q. and Zhong, D. (2020). The Impact of the Novel Coronavirus Epidemic on China's Tourism Industry and Its Countermeasures, Academic Exploration, 2020(3), 124-131.

[8] National Statistical Office of Thailand (2020). Available from: http://web.nso.go.th/

[9] Suwannaphong, K. (2020). Journal of Humanities and Social Sciences (Rajapruek University), 6(2), 44-56.

[10] Taiwan External Trade Development Council (2020). Analysis of Market Environment Analysis in Thailand. Available from: https://www.taitraesource.com/total01.asp?AreaID=00\&CountryID=TH\&tIte $\mathrm{m}=\mathrm{w} 04$

[11] TTG China (2020). ASEAN Tourism Forum: Together Towards a Next Generation of Travel. Available from:

https://cn.wtcf.org.cn/qqlx/202001164427916.html

[12] The Voice of Vietnam (2019). ASEAN Tourism Forum Opens in 2019. Available from: http://www.xinhuanet.com/world/201901/15/c_1123989533.htm 
[13] UDN (2020). The Epidemic Seriously Damages the Tourism Industry, and Thailand's Economy Shrank for the First Time in Six Years. Available from: https://udn.com/news/story/6811/4573402

[14] Wang, W., Zang, B., Ma, M. and Hu, G. (2009). Measures Research on the Development of Thailand Tourism Economy, Human Resource Management, 2009(3), 25-26.

[15] Wu, P. (2014). A Preliminary Study on the Factors of Sustainable Development of Thailand's Tourism Economy, Logistic Engineering and Management, 2014 (10), 128-130.

[16] Yan, W. and Yan, S. (2020). Influence of COVID-19 on Tourism Development and Countermeasures. Commercial Times, 11, 190-192.

[17] Yang, F. (2017). Research on Tourism Development in Thailand, COOperative Economy \& Science, 2017 (10), 50-51.

[18] Yin, R. (1994). Case Study Research: Design and Methods, Beverly Hills, CA: Sage. 